\title{
CHAMBERLINESS AS A SEMANTIC DOMINANT OF INSTRUMENTAL ENSEMBLE CREATIVITY
}

\section{Povzun L. I.}

\section{INTRODUCTION}

In the modern performing practice, the problem of chamberliness is of particular relevance, as evidenced by both the artistic sphere as a whole and the field of musical chamber instrumental and ensemble creativity, marked by the emergence of new "genre mixes", new timbre and instrumental combinations, new criteria for the organization of musical ensemble performances space. There is a significant extension of the traditional notion of chamberliness; chamber and instrumental genre varieties that are at the intersection of features are becoming widespread: orchestral and ensemble (performance of chamber and ensemble works by chamber orchestra), instrumental and ensemble (with the conductor's involvement in ensemble performance) and vocal-instrumental and ensemble (introduction of vocal voice into ensembles).

In the system of instrumental and ensemble genres, chamberliness appears as a semantic structure, which is formed by a complex artistic and communicative construct of "author - composition - performer - ensemble acoustic space - listener", whose action contributes to the multiplication of meanings with the unquestionable primacy of semantic copyright and artistic content. We consider the structural and semantic components of the chamber by the semantic hierarchy as:

- semantic intentions of the work, which activate and mobilize the intellectual potential of the performers, forming the "existential mix" of the content;

- creative interaction of small compositions of performers who carry out personal and psychological, technological, artistic interpretation of the author's text, forming a "thesaurus performing continuum";

- listeners' openness and psychological readiness for "immersion" in the deep-philosophical layers of the author's plan in different historical and aesthetic conditions of performing embodiment;

- timbre and instrumental compositions, selected by historical musical performing practice for reproduction of artistic and semantic foundations of chamberliness and canonized in chamber and instrumental works by composers of different styles;

- stylistic system that embraces several structural layers of composition (related to genre and form, music material, context of existence 
and processes of perception) and combines genre variations of the chamber ensemble in the works of different authors, different national schools and historical eras.

\section{Genre and semantic features of chamberliness}

There is identified a number of representatives of "chamber music" and "chamber ensemble", forming music dictionaries, encyclopedias, in the study, dedicated to problematic performers and composers. In their definitions, accents are made on a quantity aspect (small with the participation of participants), on acoustic conditions (closed spaces), on the genre differences from the theatre, symphonic, concert music, however, certain differences of chamber music are not defined: there is one leading differential feature, which implies the objective compliance of the work with communicative requirements - the conditions of performance.

Like each of the groups of concert, theater, symphonic genres, the sphere of chamber music is characterized by certain aesthetic norms, peculiarities of social and cultural existence, a specific image sphere, as well as material, purely physical, conditions, timbre and instrumental characteristics, dynamic indicators. Referring to the concept of $\mathrm{M}$. Aranovskyi, we note that each genre has an external and internal structure - the parties that the genre encounters with the outside world and which ensure its social engagement, and the parties that determine its immanence and ensure its continuity in time. The external nature of the genre as a way of existence of a musical composition reproduces its "ontological essence", while the internal structure is largely related to cognitive functions, with the "genetic code" of the genre, implies a whole set of necessary components: belonging to a certain kind of art, sound source, applied possibilities, structural and semantic invariant ${ }^{1}$.

Continuing the scientist's argument, we determine that the "external" form of chamber and instrumental genres is the observance of certain conditions of performance (orientation to small spaces, small number of performers and a small audience), while the "internal" form has special semantic properties, meaning related to the reproduction of the existential foundations of human consciousness. The "outer" side of the phenomenon has the ability to modify and it is not an established characteristic of chamber instrumental and ensemble genres. And it was in the "external form" that in the initial stage of the formation of instrumental and ensemble music - in the Baroque period - chamber music was separated from the church, and the conditions of performance differentiated in many ways similar instrumental and ensemble genres into chamber and church. Church genres and temple

1 Арановский М. Структура музыкального жанра и современная ситуация в музыке // Музыкальный современник : сборник статей. М. : Советский композитор, 1987. Вып. 6. С. 38. 
instrumental ensemble music indirectly influenced the chamber and instrumental sphere with the artistically reflected features of the spiritual worldview. Such semantic filling of instrumental and ensemble genres (invariant of chamberliness) is contained in the whole complex of means of expression - in semantics of chamberliness. The external form is closely linked to the internal form, and the change of one component - the conditions of fulfillment - inevitably leads to the change of other components, artistic means of expression, instrumental language.

The genetic code of chamber genres contains the "semantic nucleus" of chamberliness as an orientation to the higher spiritual sphere, which is conditioned by long stay in common historical and artistic conditions with sacred music. Although in the course of development chamber and instrumental genres have been influenced by many historical and aesthetic directions, the semantic foundation - the feeling of highness, while being immersed in the innermost corners of the soul, laid in the Baroque period, is preserved as the main "memory of the genre" (M. Bakhtin's term) ${ }^{2}$.

Chamber instrumental and ensemble genres differ in qualitative and quantitative structure, conditions of performance, have different stylistic affiliation - historical or authorial, but are united by characteristic common qualities - special semantic orientation to the deep layers of human consciousness, which requires a special selection of tools specific composer and performing technique of artistic concept reproduction.

In musicological, methodological and performing literature there are phrases concerning the notion of chamberliness, which characterize the artistic properties of individual works or the style of a particular author. The term chamberliness (as an indication of intimacy, communicative and spatial constraint) occurs in the context of theoretical discussions, in musical descriptions. Appearing in the vocabulary of music as a derivative of the terms "chamber music", "chamber ensemble", the notion of chamberliness implies, first of all, the correspondence of the etymology of the word. However, since in the course of historical development chamber instrumental and ensemble performance has passed several historical and aesthetic stages (home music, secular salon, concert performance, in modern conditions - competitive, festival etc.), as a result of which a number of leading factors of this phenomenon, the conditions of performance of this phenomenon have been modified as one of the identifying genetic genre traits, cease to be the defining characteristic of the chamber and ensemble genre system, and the notion of chamberliness loses its uniqueness in the quality of domestic or salon music, acquiring the features of the genre universal.

${ }^{2}$ Бахтин М. Эстетика словесного творчества / [сост. С. Бочар, С. Аверинцев]. Изд. 2-е. М. : Искусство, 1986. С. 178. 
Chamberliness as a special semantic dimension, a separate semantic installation of instrumental and ensemble genres, by its sociocultural origin, is associated with different genre principles. On the one hand, the signs of chamberliness are inextricably linked to household dance music and instrumental ensemble home music, and on the other hand, the long history of being in temple conditions brings the imagery of chamber music closer to the sphere of philosophical generalizations, which in turn leads to differences in semantic and psychological levels, artistic content and form of works, as well as the performance tools of expressiveness. The semantic coexistence of different genre primordial causes further aesthetic, functional, spatial and acoustic universality of chamber instrumental and ensemble genres.

The process of formally dividing instrumental and ensemble music into two leading spheres - ecclesiastical (spatial and socially volumetric) and chamber (household-limited) - took place under sociocultural and contextual conditions of performance, as well as by semantic and formal parameters, which corresponded to the widespread in Baroque theories of "styles" or "manners" according to which music performed in a grand cathedral must be fundamentally different in acoustic and semantic terms from music intended for chamber rooms.

Such a position at a certain historical stage fixed the attention on the genre differences of the "outside", while the "internal", the semantic side could not be separated by quantitative or organological indicators, since the sacral sphere somehow influenced the ethos of human life; it could not be separated from any artistic action. Not only in art, but in life, the sacred is associated with the affirmation of the pathos of spirituality, with the worldviews of man.

"No matter how diverse the world of man is, whatever scientific and aesthetic problems do not attract people's attention, the highest meanings they seek in the problem of life and death, in the mystery of existence... Sacred in the world - this is a kind of... extreme points, extreme poles of the human world, "boundary "situations of extraordinary being"

The formation of semantic features of chamberliness as a genre and content concentration on the depth-personal layers of human consciousness in instrumental and ensemble creativity during the Baroque period was a kind of embodiment in the traditions of dedication to the Creator's own opus - for the ability to create, which is given to man. Subsequently, this tradition has undergone a transformation, taking the following peculiar forms:

- in the classicist era, composers, in honor and gratitude, devoted their inspiration to people of the highest social status who contributed to the development of the musical and creative sphere;

3 Личковах В. А. Некласична естетика в культурному просторі XX-поч. XXI століть : монографія. Київ : НАКККіМб, 2011. С. 25. 
- the sensual nature of romantic art gave impetus to the public expression of intimate personal thoughts in the dedication to loved ones, creating the possibility of a declaration of love "without words";

- at the present stage of dedication, they most often serve as a memorial, engaging in the memory of future generations the sonic images of historical time and the person involved.

Such semantic repetitiveness proves that the sense parameters of chamberliness correspond to three types of human activity (according to P. Florenskyi ${ }^{4}$ ) and three extra-musical prototypes (according to S. Skrebkov ${ }^{5}$ ), causing the following semantic series:

- theoretical activity - word - dedication: remote in time imaginative and existential communication with future performers / listeners;

- practical activity - gesture - play: performance of instrumentalists in accordance with the instructions of "chamber etiquette";

- sacral activity - intonation - performance: "spiritual harmony" of musicians - listeners.

The above-mentioned allows to conclude that instrumental and ensemble art has undergone a number of sociocultural assimilations, being within the chronotopic boundaries of different historical and aesthetic directions, the action of which is not limited to the traditional consideration of the conditions of performance (small rooms of house / salon music or concert space of church performance) - and the quantity parameter of performing and hearing indicators. Meaningful features of chamberliness, born of the Baroque era, exist as a genetic "nucleus" in varieties of chamber and ensemble creativity, and, supplemented by new qualities inherent in each subsequent historical epic, do not lose their specific primary sources, combining: household and trivial - exalted sacred, amateur-gaming - professionalperforming, chamber intimate - concert hopeful. The voluminous potentials of quantitatively instrumental and qualitatively timbral variability and a wide range of artistic possibilities contribute to the reproduction of all, sometimes polar, features of the semantics of chamberliness.

Thus, instrumental and ensemble genres are united in a single system by semantic dominance - chamberliness, which is a multilevel concept: in terms of performance, in qualitative and quantitative composition, in expressive means, in artistic content. However, some of these components exhibit the ability to transform:

- change of performance conditions - chamber or concert;

${ }^{4}$ Флоренский П. Столп и утверждение истины: Опыт православной теодицеи в двенадцати письмах : в 2 томах. М. : Академический проект, 2012. Т. 1.912 с.

${ }^{5}$ Скребков С. Художественные принципы музыкальных стилей / [ред. В. Панкратова]. М. : Музыка, 1973. 446 с. : нот., ил. 
- changing the quantitative composition of the ensemble - translating the work for another number of participants;

- change of quality composition of the ensemble - alternative replacement of instruments provided by the author or transcription.

However, the transformation of these factors does not change the semantic orientation of the works, provided that the performers are aware of the ambiguity of the artistic content. Specificity of chamber and ensemble genres in their modern interpretation lies in the ensemble unity of independent, individualized soloists' parties and defines an extremely wide range of expressive possibilities of instruments that are part of a certain composition and in the process of realization of the author's plans involve the use of a whole set of artistic, at first glance, "classical" (in the broad sense of the word) expressive means, such as articulation, agogic, timbre, dynamics, sound production, etc., undergo dramatic changes as they reproduce new tendencies in the field of composer techniques and philosophical and aesthetic ideas.

Having recognized the influence of many artistic and aesthetic trends, chamber instrumental and ensemble genres in the new round of their historical development, in the XXI century continue to discover new expressive and semantic possibilities. Enriched by experimental means of instrumental expression, by means of sound extraction, by acquiring new forms, they retain their semantic setting - the semantic core of chamberliness as an orientation to the higher spiritual realm.

\section{Arte da camera as a play communication system}

Arte da camera is defined as a special kind of musical art, which is formed by the semantic coherence of the three components of chamber and ensemble creativity - composer content - performing interpretation "consonant" listening audience - which determines the interaction of the communicative and emotional system - artistic performance, which was done differently in different historical periods

The genre restriction of the ensemble composition, which is an external indicator, allows to have psychological and communicative interaction between all participants and provides a direct impact on the listener of each performer (joint creativity as a harmony of the whole with the artistically perfect participation of each); limitation of the audience implies intellectual and emotional readiness for self-absorption, as well as style and performance awareness (which in the Baroque and partially classicist times was played in the free interchange of the roles of the performer and the listener).

Collaborative music playing in various instrumental ensembles has always played an important role in the musical culture of society as a form of play, highlighting the fact that play is a natural manifestation of human activity, 
but in the very naturalness of play behavior there is necessarily a "element of artificiality and conventionality" without which play would not exist ${ }^{6}$.

The word play is ambiguous, and although the etymological hypothesis binds it to music (inferring from the Greek agos - "praise and propitiation of the deity" by singing and dance), it goes far beyond the narrow semantics and absorbs a plurality of meanings (the rich range of which spans the most diverse), however, the music gene remains: the play is the lead of the instrumentalist. High tone is a prerequisite for professional performance, the basis of lightness, virtuosity, mobility. However, the musician also plays as an actor, and his highly specialized movements that control sound production, although at first glance they have no analogues in dance and other motionrelated fields, at the same time in his organization, the intonation and plastic sense becomes the kinetic basis for gesture, play action ${ }^{7}$.

Chamber instrumental and ensemble music in the Baroque period was chronotopically distinguished as a specific sociocultural play, subordinate to the leading ideas of time - "geringe Invention" - the ability of the invention as the implementation of the principles of variability and the introduction of rules and canons, which led to the aesthetic understanding of chamberliness as a genre and style paradigm of ensemble works, which manifests itself in the reproduction of a certain communicative situation, the spatial qualities of which affect the timbral, dynamic, articulatory properties of instrumental and ensemble sound.

The creative process was interpreted as a rationalistic, orderly and sequential action, accompanied by a considerable emotional uplift, while at the same time; there is a tradition in the composer's circles of the author's "dedication" to opuses to thank the Creator and nature for the gift of inspiration.

This understanding of artistic activity resonates with the notion of "objective, historical spirit", since it is the objective spirit that is the creative factor of the artist's actions and the stylistic basis of the cultural form and art performs a cultural, even metaphysical, function. It is to objectify the spirit of the era, the aesthetic expression of which in art makes the objective spirit accessible for direct contemplation and deep experience ${ }^{8}$.

According to J. S. Matheson, the main stages of the creative process should be embodied in four concepts borrowed from rhetoric: invention (invention), disposition (arrangement), elaboration (decoration) ${ }^{9}$.

\footnotetext{
${ }^{6}$ Мазрова Н. Философский смысл игры в моделировании социальной реальности: автореф. дис. канд. философ. наук: специальность: 09.00.11. М., 2004. 17 с.

7 Назайкинский Е. Стиль и жанр в музыке : [учебное пособие для студентов высших учебных заведений]. М. :Гуманитарный изд. центр «ВЛАДОС», 2003. С. 173.

${ }_{8}^{8}$ Личковах В. А. Некласична естетика в культурному просторі XX-поч. XXI століть : монографія. Київ : НАКККіМб, 2011. С. 8.

${ }^{9}$ Mattheson J. Der vollkommene Capellmeister. Hamburg : C. Herold, 1739 : Faksimile. Nachdruk. Hrsg. Von Margarete Reimann. Kassel, Barenreiter, 1991. 5. Aufl. 485 s.
} 
In the aesthetics of Baroque particular importance was attached to the first two stages: the ability of the invention was considered one of the main qualities of genius. Deriving the word "genius" (gegnere - to generate, produce), K. Helvetius noted that inventions or discoveries are of two kinds, some of us are bound by chance; there are other discoveries that we owe to genius - and here the word "discoveries" refers to a new combination, a new relation, which has emerged between known things or ideas ${ }^{10}$.

The Invention-tendency acted both from "inside" of the chamber and ensemble genre sphere (in compositional structures) and "outside" (in ensemble chronotope), creating a single listening and performing space, subject to the common rules of performance perception (free spatial and sense transformation of listeners and artists during the music play).

Free play, as the most characteristic feature of the Baroque era, occurred at different levels of performance:

- play by compositional structures of the author's text - variant presentation of the cyclicality of ensemble works (permutation of parts, repetition of sections at the discretion of the performers); rhetorical decorations in most cases embodied the sphere of creative imagination of performers; the performer of the basso continuo became to some extent the coauthor of the work;

- play instrumental compositions - their quantitative and timbral combinations;

- play of space and sound density categories taking into account timbre and dynamic properties of ensemble composition.

Free movement of components within a single semantic complex formed a leading feature of chamber instrumental and ensemble performance personal interaction of performers without authoritarian intervention of the conductor: free play is possible under the same rules for all participants, allowing to build a collective aesthetic harmony, a key feature of the play ${ }^{11}$ ).

This phenomenon was prolonged in the further development of genres of chamber ensemble in the following epochs:

- the principles of the author's alternative replacement of ensemble instruments were in demand in the compositions of classics and romantics, as well as in the translation of chamber works for another instrumental composition, which actualized a different instrumental and variant model of performance;

- playing with timbral and organologically-dynamic properties becomes an artistic idea of the work;

${ }^{10}$ Гельвеций К. Сочинения : в 2 т. / [сост., общ. ред. Х. Н. Момджяна]. М. : Мысль, 1973. Т. 1. С. 482-483. .

${ }^{11}$ Хейзинга Й. Homo ludens. В тени завтрашнего дня / [пер. с нидерланд.]. М. : Прогресс, 1992. С. 13.. 
- chamber and ensemble genres with extraordinary potential of playing possibilities (articulatory, timbral, sound-like) become a field of realization of experimental instrumental searches for composers;

- playing activities extend to the semantic multiplicity of instrumental roles: one performer is entrusted with the simultaneous reproduction of several parties (a kind of "split" of the performing personality) in the ensemble works of contemporary authors.

In contrast to the traditional definition of the concept of play as a type of unproductive activity, the motive of which is not in the results, but in the process, instrumental and ensemble performance is a play for the sake of the end result - achieving a higher degree of self-realization in the harmonious structure of joint actualization of the artistic composition (by O. Samoilenko "adherence to the highest semantic order" ${ }^{12}$ ).

Thus, in the initial stages of the formation of instrumental and ensemble genres, the chamberliness was predominantly a spatial category of "restrictions" (limited conditions of performance, limited formulations, a limited number of listeners), in the process of ontological development of genres, becomes a semantic category that determines the semantic basis of the existence of genres and at the same time creates opportunities for the release, reincarnation, and opening of new viable factors for development (which, according to J. Heising, is the second rule of the play ${ }^{13}$ ).

Aesthetic criteria of chamberliness give birth to an aspirational desire to establish a "perfect order", which implies a harmonious unification of the various to create a common artistic whole: in such conditions, the traditional notions of "mine" - "alien" find a new interpretation, since the ensemble's closed "performing micro-space" becomes "its" perfect playing space for selfrealization of each participant.

In the chamber and ensemble genres close communication between the performers and listeners, personal interaction of the performers create a specific intimate atmosphere of music (in "its" space), which allows you to dive into deeper layers of human consciousness, personal feelings, as these listeners are thoughts - in such a social context it is impossible to misunderstand or reject the music being played.

In various conditions of existence - in the salon, in various academies and circles - the rules of good tone prescribed "superficially uninterested pleasure" chamber and ensemble music. Thus, in the beginning of the XVI century B. Castiglione in the treatise "On the court" emphasized that a

12 Самойленко А. Музыкознание как «живая история» культуры: К проблеме диалогичности гуманитарного знания // Трансформація музичної освіти: культура та сучасність: матеріали музикологічного семінару. Одеса : Астропринт, 1998. Ч. 1. С. 91-102.

${ }_{13}$ Хейзинга Й. Homo ludens. В тени завтрашнего дня / [пер. с нидерланд.]. М. : Прогресс, 1992. С. 13. 
noble person who sings, creates music or listens, should not be too deep into music, he should hide his interest, acting as a person emotionally educated, like deprived, superficial, immediate emotionality ${ }^{14}$.

The practice of half-hearing, free inclusion in the process of perception, and equally spontaneous exclusion remained the norm until the end of the XVIII century. In such circumstances, which did not require a long and thoughtful listening to a long composition, the authors could not be guided by the dramaturgy and conceptualization of the artistic whole, thus adjusting their genre priorities accordingly. And so, a way of thinking musically and genre models formed by them that would allow discretion of perception (without losing the aesthetic appeal) and be an organic part of the established listening ritual should become leading.

The genre restriction of the audience implied not the restriction of quantitative composition, but the presence of the listening elite, which is in the same "style field" with the performers, which in Baroque and partially classical times was played in the free interchange of the roles of performer and listener. The prolongation of this process (psychological unity of the performing and listening "style field") is also observed in contemporary music: concerts of chamber and ensemble music, irrespective of the conditions of performance (chamber or concert hall), require a certain intellectual and psychological readiness of the listeners.

Playing entertainment that was inherent in the ensemble creativity in the initial stages (in the "golden age of instrumentalism") and provided some theatricalization in connection with the timing of specific events, subsequently, in the transfer of instrumental and ensemble music to the presented genres, and conditioned transformed into the rules of "chamber etiquette" in the performance of ensembles, in particular:

- tradition of public speaking and greetings;

- procedure for adjusting tools;

- mise-en-stage criteria of arrangement of chamber and ensemble genre varieties;

- coordination of the performing middle stage for auditory and visual control;

- supremacy of presentation of "performance affect" to the audience.

Professional ensemble skill goes beyond the procedure of musicplaying and becomes the performing art of the aggregate artistic whole sound harmonization, forming a conceptual series: music - performance performance. The correlation of the processes of music playing (as a free play), performance (as a professional play) and performance (as the highest

14 Музыкальная эстетика западноевропейского средневековья и Возрождения. М. : Музыка, 1966. С. 523. 
form of skill in the play) in the historical perspective is due to numerous artistic, aesthetic, sociocultural and national factors.

At the turn of the XX-XXI centuries the concept of chamber ensemble begins to include the concept of instrumental theater in its subject content; the latter receives a plurality of individually-authorial manifestations and provides, in addition to purely sound realization of the composition, instrumental-acting actions of the performers, thereby increasing the importance of the performing factor in the process of the artistic plan embodiment. The performance aspect becomes a decisive factor in the instrumental and ensemble creativity of the modern period, since the final (cathartic) result of the artistic actualization of the composition depends largely on the skill and artistry of the instrumentalists.

Establishment of chamber and ensemble genres on the concert stage introduced the features of theatricalization (as a set of specific means and techniques inherent in theatrical art) into performing and instrumental action, which are manifested by:

- performance by the instrumentalist (party) in a specific role in the musical composition; as the "instrumental mask" play - a play in a play;

- in a specific manner / method / reception of artistic and instrumental embodiment;

- in conscious underlining of tools of expressiveness - supremacy, supra-dynamics of instrumental representation;

- in the active use of additional visual aids - facial expressions, gestures, stage action;

- through the interaction of several genres: instrumental music words, - dance, - video series, - stage action.

A specific continuation of the "instrumental masks" play is the tendency for "universal instrumentalism" - bi-instrumental use of performers in the ensemble (in particular, the performance of the pianist as a keyboardist and vocalist; a combination of piano and percussion party; instrumental party and verbal series) a historical dialogue with the Baroque era, when the standard of the perfect ensemble was the ability to master all instruments of composition.

Theatricalization of the performing arts leads to the transformation of the traditional spatial relations of "performer and listener", initiating the extension of the boundaries of the listening space due to the appearance of video space, translating the scheme of communication into a series of "performer - listener - viewer". 


\section{CONCLUSIONS}

The notion of chamberliness implies an acoustic and spatial correspondence with the etymology of the word camera: focus on the limited spaces of home music, small instrumental formulations, and a small audience. In the course of historical development, chamber instrumental and ensemble music has undergone a number of aesthetic and sociocultural stages - home music, secular lounge, concert performance, competition and festival movement, as a result of which a number of leading phenomenon factors have acquired new qualities. Therefore, the conditions of performance, as one of the leading genetic genre traits, cease to be the defining characteristic of the system of chamber and ensemble genres, and the concept of chamberliness loses its uniqueness of quality of house or salon music, acquiring a feature of space-acoustic versatility.

The genetically determined emotional elitism of chamber music forms the communicative system of Arte da camera, which is formed by the semantic consistency of the components: the composer's content - the performer's interpretation - the "consonant" listening audience.

Chamberliness as a genetic and semantic core of instrumental and ensemble creativity forms a multilevel genre system of chamber ensemble, in the construction of which the dominant classification criterion is the semantic nucleus of chamberliness - the spiritual outlook of the artists, which acquires artistic and semantic expression of genre varieties, processes of formation of specifically performing expression means; determines the spatial and aesthetic conditions of performing embodiment.

The semantic concentration of chamberliness on the deeppsychological layers of human consciousness has found a special form of embodiment in the traditions of dedication to musicians of their own works: in the Baroque - the Creator for the ability to be creative; in the classicist era fans and patrons; in romantic times - loved and beloved; at the present stage the majestic personality of the artist. The semantic repetitiveness of the initiates builds a semantic series that determines the category of chamberliness to belong to three types of human activity (theoretical, practical, and sacred) and three extra-musical prototypes (words, gesture, intonation):

- theoretical activity - word - dedication: delayed personal and author communication with potential performers / listeners;

- practical activity - gesture - play: tactile and semantic involvement in the author's idea of the work;

- sacral activity - intonation - performance: existential community of musicians - listeners in the awareness of "extremes" of human life.

The notion of chamberliness, which genetically determined the spatial conditions of music and was a characteristic of non-musical components, in the process of researching the historical and aesthetic, artistic and semantic 
factors of instrumental and ensemble creativity revealed the semantic ambiguity of the phenomenon of chamberliness as a genre and style dominant of a set of musical components and elements of musical order. Despite the significant differences in the organological structure of ensembles, the variant acoustic and aesthetic possibilities of the existence of chamber and ensemble genres / works and their stylistic (historical and author's) affiliation, which determines the integrity of the chamber instrumental and ensemble genres, chamberliness gives a meaningful spiritual core of artists that acquires artistic and semantic completeness in a series of creative reproductions of a complex artistic and communicative construct "author composition- performer - ensemble - acoustic and space - the listener / viewer", which promotes interaction of meanings multiplication in a creative realization of artistic intent.

\section{SUMMARY}

Chamberliness as a special semantic dimension, a separate semantic setting of instrumental and ensemble genres, by its sociocultural origin, is connected with different genre basics. This causes corresponding differences between the semantic and psychological levels, artistic content and form of works, performing means.

In the system of instrumental and ensemble genres, chamberliness appears as a semantic structure, which is formed by a complex artistic and communicative construct "author - composition - performer - ensemble acoustic simple - listener", whose action contributes to the multiplication of meanings with the undisputed right of semantic copyright content and artistic performance primacy.

Structural and semantic hierarchy components of the chamber are constructed as: semantic intentions of the composition, which activate the intellectual potential of the performers, forming the "existential mix" of the content; creative interaction of small compositions of performers who carry out personal and psychological, technological, artistic interpretation of the author's text, forming a "thesaurus performing continuum"; the listener's openness and psychological readiness to "dive" into the deep philosophical layers of the author's plan in different historical and aesthetic conditions of performing embodiment; timbre and instrumental compositions selected by historical musical performing practice for reproduction of artistic and semantic principles of chamberliness and canonized in chamber and instrumental works by composers of different styles; a style system that embraces several structural layers of a composition (related to genre, form, musical material, context of existence and processes of perception) and combines genre variations of the chamber ensemble in the works of different authors, different national schools and historical eras. 


\section{REFERENCES}

1. Арановский М. Структура музыкального жанра и современная ситуация в музыке // Музыкальный современник: сборник статей. М. : Советский композитор, 1987. Вып. 6. С. 5-44.

2. Бахтин М. Эстетика словесного творчества / [сост. С. Бочар, С. Аверинцев]. Изд. 2-е. М. : Искусство, 1986. С. 9-191.

3. Гельвеций К. Сочинения : в 2 т. / [сост., общ. ред. Х. Н. Момджяна]. М. : Мысль, 1973. Т. 1. 647 с.

4. Личковах В. А. Некласична естетика в культурному просторі XX - поч. XXI століть : монографія. Київ : НАКККіМб, 2011. 224 с. [167, c. 25]. [167, c. 8].

5. Мазрова Н. Философский смысл игры в моделировании социальной реальности: автореф. дис. канд. философ. наук: специальность: 09.00.11. М., 2004. 17 с.

6. Музыкальная эстетика западноевропейского средневековья и Возрождения. М. : Музыка, 1966. 568 с.

7. Назайкинский Е. Стиль и жанр в музыке : [учебное пособие для студентов высших учебных заведений]. М. :Гуманитарный изд. центр «ВЛАДОС», 2003. 248 с.

8. Самойленко А. Музыкознание как «живая история» культуры: К проблеме диалогичности гуманитарного знания // Трансформація музичної освіти: культура та сучасність: матеріали музикологічного семінару. Одеса : Астропринт, 1998. Ч. 1. С. 91-102.

9. Скребков С. Художественные принципы музыкальных стилей / [ред. В. Панкратова]. М. : Музыка, 1973. 446 с. : нот., ил.

10. Хейзинга Й. Homo ludens. В тени завтрашнего дня / [пер. с нидерланд.]. М. : Прогресс, 1992. 458 с. [341, с. 13]).

11. Mattheson J. Der vollkommene Capellmeister. Hamburg : C. Herold, 1739 : Faksimile. Nachdruk. Hrsg. Von Margarete Reimann. Kassel, Barenreiter, 1991. 5. Aufl. 485 s.

\section{Information about the author: \\ Povzun L. I.,}

Doctor of Art Studies,

Professor of the Department of Chamber Ensemble, Head of the Department of Chamber Ensemble, Odessa National A. V. Nezhdanova Academy of Music 63, Novoselskogo str., Odessa, 65023, Ukraine 